\title{
Systemic inflammation modulates the ability of serum ferritin to predict all-cause and cardiovascular mortality in peritoneal dialysis patients
}

Sha Fu', Junzhe Chen ${ }^{\dagger}$, Bo Liư ${ }^{\dagger}$, Peifen Liang, Yuchun Zeng, Min Feng, Zhenjian Xu, Guiqiong Zheng, Suqiong Yang, Anping $\mathrm{Xu}$ and Ying Tang ${ }^{*}$

\begin{abstract}
Background: This study aimed to ascertain whether the correlation of high serum ferritin with mortality is affected by systemic inflammation and to investigate the optimal serum ferritin level for predicting death when inflammation is considered in peritoneal dialysis (PD) patients.

Methods: We classified 221 patients into four groups according to serum ferritin concentration $(100 \mu \mathrm{g} / \mathrm{L})$ and high-sensitivity CRP (hs-CRP) level (3 mg/L), and followed them regularly from the date of catheterization to Dec 31, 2016, at Sun Yat-Sen Memorial Hospital, China. Clinical and biochemical data were collected at baseline, and clinical outcomes such as all-cause and cardiovascular mortality were assessed.

Results: During a median follow-up of 35 months (3 109 months), 50 (22.6\%) deaths occurred. Cardiovascular disease (46.0\%) was the most common cause of death, followed by infection (10.0\%). The Kaplan-Meier survival analysis and log-rank test revealed significantly worse survival accumulation among PD patients with higher serum ferritin $(\geq 100 \mu \mathrm{g} / \mathrm{L})$ under elevated hsCRP levels $(>3 \mathrm{mg} / \mathrm{L})(P=0.022)$. A multivariate Cox regression analysis revealed that an increased serum ferritin level was independently associated with a higher risk of all-cause and cardiovascular mortality in PD patients $(H R=3.114, P=0.021$; and $H R=9.382, P=0.032)$ with hsCRP above $3 \mathrm{mg} / \mathrm{L}$ after adjusting for relevant confounding factors.

Conclusion: Higher serum ferritin levels were associated with an increased risk of all-cause and cardiovascular mortality in patients undergoing PD only in the presence of elevated hsCRP levels. The correlation of serum ferritin with poor outcome should take into consideration systemic inflammation.
\end{abstract}

Keywords: Inflammation, Serum ferritin, High-sensitivity C-reactive protein, Peritoneal dialysis, Mortality

\footnotetext{
* Correspondence: tangy26@mail.sysu.edu.cn

${ }^{\dagger}$ Sha Fu, Junzhe Chen and Bo Liu contributed equally to this work. Department of Nephrology, SunYat-Sen Memorial Hospital, Sun Yat-Sen University, 107 Yanjiang West Road, Guangzhou 510080, China
}

(c) The Author(s). 2020 Open Access This article is licensed under a Creative Commons Attribution 4.0 International License, which permits use, sharing, adaptation, distribution and reproduction in any medium or format, as long as you give appropriate credit to the original author(s) and the source, provide a link to the Creative Commons licence, and indicate if changes were made. The images or other third party material in this article are included in the article's Creative Commons licence, unless indicated otherwise in a credit line to the material. If material is not included in the article's Creative Commons licence and your intended use is not permitted by statutory regulation or exceeds the permitted use, you will need to obtain permission directly from the copyright holder. To view a copy of this licence, visit http://creativecommons.org/licenses/by/4.0/ The Creative Commons Public Domain Dedication waiver (http://creativecommons.org/publicdomain/zero/1.0/) applies to the data made available in this article, unless otherwise stated in a credit line to the data. 


\section{Background}

Accumulating evidence has demonstrated that inflammation is negatively associated with the mortality and residual renal function of peritoneal dialysis (PD) patients. Serum ferritin is widely recognized as an acute phase reactant, that is nonspecifically enhanced under systemic inflammatory conditions, including chronic kidney disease (CKD), liver disease, and cancer [1-4]. Higher serum ferritin levels can induce macrophage accumulation and increase reactive oxygen species (ROS) formation during inflammation [5]. It was recently noted that serum ferritin concentration is highly correlated with mortality and cardiovascular outcome in maintenance hemodialysis patients (MHD) [6, 7]. However, the effect of serum ferritin on the long-term outcome of PD patients remains unclear.

Systemic inflammation is usually assessed by Creactive protein (CRP) levels which have been widely considered to be associated with all-cause and cardiovascular mortality in patients undergoing dialysis [8]. High-sensitivity CRP (hs-CRP) is more sensitive than conventional CRP and a better marker for predicting 5year mortality and dropout among PD patients $[9,10]$. Recent studies have shown that persistent inflammation exacerbates the effects of risk factors that predict the poor outcome of CKD patients, such as serum albumin and osteoprotegerin $[11,12]$. Therefore, we hypothesized that systemic inflammation might serve as a catalyst and modulate the effect of serum ferritin on the long-term prognosis of PD patients. We hence undertook this study to (1) ascertain the serum ferritin level that is negatively associated with the long-term survival of PD patients and (2) investigate whether the predictive role of serum ferritin is affected by hsCRP levels.

\section{Methods \\ Patients}

This retrospective, observational, cohort study enrolled 221 patients with end-stage kidney disease (ESKD) who underwent percutaneous PD catheter insertion in our hospital and had been undergoing PD more than 3 months. The PD modality was Continuous Ambulatory Peritoneal Dialysis (CAPD) using glucose-containing dialysis fluid which was exchanged four or five times daily. All patients with anemia were on erythropoiesisstimulating agent (ESA) therapy and received iron supplementation (intravenous or oral iron) if transferrin saturation (TSAT) $\leq 30 \%$ and ferritin $\leq 500 \mu \mathrm{g} / \mathrm{L}$. This study was conducted in the PD center of Sun Yat-sen Memorial Hospital, China, from October 2007 to December 2016. Patients with a duration of maintenance PD of less than 3 months were excluded.

The study and protocol were reviewed and approved by the Medical Ethics Committee of SunYat-Sen
Memorial Hospital, Sun Yat-Sen University. We reviewed and followed up the medical data according to the guidelines of our ethics committee. Oral informed consents from PD patients were obtained if we followed up by telephone. The follow-up period was from the time of percutaneous PD catheter insertion to 31 December 2016. Patients were followed up to monitor deaths including all-cause and cardiovascular deaths. Cardiovascular mortality was defined as death from acute myocardial infarction, arrhythmia, heart failure, cerebral hemorrhage, cerebral infarction or sudden death.

\section{Data collection}

Baseline demographic and clinical parameters, including age, gender, body mass index (BMI), primary renal disease, laboratory data, and dialysis information prior to the first PD session, were obtained from the medical records and recorded in a special PD registration form. Blood samples were drawn prior to PD catheter insertion at the time of hospitalization and were collected under the same conditions. Available laboratory data included $24 \mathrm{~h}$ urine amount, systolic blood pressure (SBP), diastolic blood pressure (DBP), Kt/V, PET D/Pcr, blood urea nitrogen (BUN), creatinine, phosphorus, calcium, cholesterol, triglyceride, LDL-C, HDL-C, apolipoprotein A, serum ferritin, uric acid, hs-CRP, albumin, prealbumin, hemoglobin, Fe (iron) and TSAT. Total Kt/V was calculated as the sum of renal and peritoneal $\mathrm{Kt} / \mathrm{V}$ using the urea clearances from 24-h urine and dialysate effluent collections. TSAT was calculated as the ratio of serum iron to transferrin binding capacity. The peritoneal equilibration test (PET), which characterizes peritoneal membrane transport, was performed to calculate the ratio of creatinine concentration in the dialysate to that in plasma after a 4-h dwell (D/Pcr).

\section{Statistical analysis}

Descriptive results of continuous variables are expressed as the mean \pm standard deviation (SD), and categorical variables are reported as percentages and numbers. Comparisons between groups were analyzed using oneway analysis of variance and the chi-squared test. The Spearman rank test was performed to estimate the correlations between serum ferritin and other variables. Allcause and cardiovascular mortality rates were assessed by Kaplan-Meier survival analyses with the log-rank test. Univariate Cox proportional hazards regression was applied to estimate the relative risk of possible factors associated with all-cause and cardiovascular mortality. To adjust for confounding factors, multivariate Cox regression analysis with forward regression was performed (factors with $P<0.10$ in the univariate analysis were added in). A $P$ value $<0.05$ was considered to indicate 
Table 1 Baseline characteristics of all, high ferritin and low ferritin patients

\begin{tabular}{|c|c|c|c|c|c|c|}
\hline & \multirow{2}{*}{$\begin{array}{l}\text { All patients } \\
(n=221)\end{array}$} & \multicolumn{2}{|c|}{ Ferritin $\geq 100 \mu \mathrm{g} / \mathrm{L}(n=152)$} & \multicolumn{2}{|c|}{ Ferritin < $100 \mu \mathrm{g} / \mathrm{L}(n=69)$} & \multirow[t]{2}{*}{$P$} \\
\hline & & $\begin{array}{l}\text { hsCRP }>3 \mathrm{mg} / \mathrm{L} \\
(n=96)\end{array}$ & $\begin{array}{l}\text { hsCRP } \leq 3 \mathrm{mg} / \mathrm{L} \\
(n=56)\end{array}$ & $\begin{array}{l}\mathrm{hsCRP}>3 \mathrm{mg} / \mathrm{L} \\
(n=45)\end{array}$ & $\begin{array}{l}\text { hsCRP } \leq 3 \mathrm{mg} / \mathrm{L} \\
(n=24)\end{array}$ & \\
\hline Ferritin, $\mu \mathrm{g} / \mathrm{L}$ & $291.4 \pm 334.1$ & $435.3 \pm 384.2$ & $355.4 \pm 266.1$ & $42.1 \pm 26.0$ & $36.1 \pm 24.1$ & 0.000 \\
\hline \multicolumn{7}{|l|}{ Demographics } \\
\hline Age, years & $53.0 \pm 14.1$ & $55.0 \pm 14.6$ & $52.5 \pm 13.0$ & $52.5 \pm 16.1$ & $47.8 \pm 10.8$ & 0.308 \\
\hline Male, n (\%) & $122(55.5)$ & $63(65.6)$ & $34(60.7)$ & $22(48.9)$ & $3(12.5)$ & 0.000 \\
\hline Body mass index, kg/m2 & $22.6 \pm 4.6$ & $21.9 \pm 4.2$ & $22.0 \pm 4.7$ & $22.5 \pm 3.7$ & $21.3 \pm 3.9$ & 0.377 \\
\hline \multicolumn{7}{|l|}{ Causes of ESKD, \% (n) } \\
\hline Chronic glomerulonephritis & $93(42.1)$ & $30(31.3)$ & $32(57.1)$ & $20(44.4)$ & $11(45.9)$ & 0.018 \\
\hline Diabetes mellitus & $51(23.1)$ & $21(21.9)$ & $11(19.6)$ & $13(28.9)$ & $6(25.0)$ & 0.716 \\
\hline Hypertension & $31(14.0)$ & $20(20.8)$ & $3(5.4)$ & $7(15.6)$ & $1(4.2)$ & 0.027 \\
\hline Obstructive nephropathy & $18(8.1)$ & $9(9.4)$ & $3(5.4)$ & $4(8.9)$ & $2(8.3)$ & 0.847 \\
\hline Lupus nephritis & $17(7.7)$ & $9(9.4)$ & $3(5.4)$ & $1(2.2)$ & $4(16.7)$ & 0.143 \\
\hline Others & $11(5.0)$ & $7(7.2)$ & $4(7.1)$ & $0(0.0)$ & $0(0)$ & 0.154 \\
\hline \multicolumn{7}{|c|}{ Deaths } \\
\hline All-cause death, \% (n) & $50(22.6)$ & $31(32.3)$ & $8(14.3)$ & $8(17.8)$ & $3(12.5)$ & 0.025 \\
\hline Cardiovascular death, \% (n) & $23(10.4)$ & $15(15.6)$ & $3(5.3)$ & $3(6.7)$ & $2(8.3)$ & 0.163 \\
\hline \multicolumn{7}{|l|}{ Biochemical parameters } \\
\hline $24 \mathrm{~h}$ Urine Amount, mL & $1366.8 \pm 639.5$ & $1326.5 \pm 636.0$ & $1371.9 \pm 638.1$ & $1347.0 \pm 667.1$ & $1427.8 \pm 711.1$ & 0.952 \\
\hline $\mathrm{SBP}, \mathrm{mmHg}$ & $156.0 \pm 21.7$ & $157.8 \pm 20.5$ & $153.0 \pm 24.0$ & $153.0 \pm 23.9$ & $159.0 \pm 24.0$ & 0.416 \\
\hline $\mathrm{DBP}, \mathrm{mmHg}$ & $87.8 \pm 13.4$ & $88.2 \pm 12.5$ & $86.5 \pm 13.0$ & $87.8 \pm 14.8$ & $89.1 \pm 15.9$ & 0.871 \\
\hline $\mathrm{Kt} / \mathrm{N}$ & $2.0 \pm 0.6$ & $2.0 \pm 0.6$ & $2.3 \pm 1.0$ & $2.0 \pm 0.4$ & $2.0 \pm 0.4$ & 0.739 \\
\hline PET D/Pcr & $0.7 \pm 0.1$ & $0.6 \pm 0.1$ & $0.7 \pm 0.1$ & $0.7 \pm 0.1$ & $0.7 \pm 0.1$ & 0.484 \\
\hline BUN, mmol/L & $29.6 \pm 12.6$ & $29.7 \pm 13.8$ & $31.7 \pm 12.0$ & $27.2 \pm 12.0$ & $29.3 \pm 9.4$ & 0.377 \\
\hline Creatinine, $\mu \mathrm{mol} / \mathrm{L}$ & $790.6 \pm 258.0$ & $785.8 \pm 282.0$ & $807.2 \pm 211.3$ & $812.0 \pm 253.2$ & $742.9 \pm 273.3$ & 0.731 \\
\hline $\mathrm{eGFR}, \mathrm{mL} / \mathrm{min} / 1.73 \mathrm{~m} 2$ & $6.0 \pm 2.6$ & $6.4 \pm 2.7$ & $5.3 \pm 2.2$ & $5.6 \pm 2.1$ & $6.1 \pm 3.4$ & 0.271 \\
\hline Phosphorus, mmol/L & $2.0 \pm 0.6$ & $2.1 \pm 0.7$ & $2.1 \pm 0.6$ & $2.0 \pm 0.6$ & $2.1 \pm 0.5$ & 0.854 \\
\hline Calcium, mmol/L & $1.9 \pm 0.3$ & $1.9 \pm 0.3$ & $2.0 \pm 0.3$ & $1.9 \pm 0.3$ & $2.0 \pm 0.2$ & 0.431 \\
\hline Cholesterol, mmol/L & $4.7 \pm 1.5$ & $4.7 \pm 1.7$ & $4.7 \pm 1.3$ & $4.6 \pm 1.2$ & $5.4 \pm 1.6$ & 0.153 \\
\hline Triglyceride, mmol/L & $1.7 \pm 1.0$ & $1.6 \pm 1.0$ & $1.7 \pm 0.9$ & $1.8 \pm 1.1$ & $1.7 \pm 1.1$ & 0.787 \\
\hline LDL-C, mmol/L & $2.9 \pm 1.1$ & $2.9 \pm 1.2$ & $2.9 \pm 1.0$ & $3.1 \pm 1.1$ & $3.1 \pm 1.1$ & 0.745 \\
\hline $\mathrm{HDL}-\mathrm{C}, \mathrm{mmol} / \mathrm{L}$ & $1.1 \pm 0.3$ & $1.1 \pm 0.3$ & $1.1 \pm 0.3$ & $1.1 \pm 0.3$ & $1.3 \pm 0.4$ & 0.067 \\
\hline apolipoproteinA, g/L & $1.0 \pm 0.2$ & $1.0 \pm 0.3$ & $1.1 \pm 0.2$ & $1.0 \pm 0.2$ & $1.1 \pm 0.3$ & 0.319 \\
\hline Uric acid, $\mu \mathrm{mol} / \mathrm{L}$ & $538.0 \pm 140.2$ & $552.0 \pm 138.9$ & $550.0 \pm 126.6$ & $493.2 \pm 136.2$ & $539.5 \pm 169.8$ & 0.132 \\
\hline hs-CRP, mg/L & $21.0 \pm 36.3$ & $37.1 \pm 43.2$ & $0.7 \pm 0.1$ & $20.3 \pm 35.0$ & $1.1 \pm 0.8$ & 0.000 \\
\hline Albumin, g/L & $32.7 \pm 5.4$ & $31.9 \pm 5.2$ & $34.3 \pm 6.0$ & $32.3 \pm 4.6$ & $33.0 \pm 5.7$ & 0.067 \\
\hline Prealbumin, $\mathrm{g} / \mathrm{L}$ & $0.3 \pm 0.2$ & $0.3 \pm 0.1$ & $0.4 \pm 0.1$ & $0.4 \pm 0.3$ & $0.3 \pm 0.1$ & 0.145 \\
\hline Hemoglobin, g/L & $82.0 \pm 20.0$ & $78.9 \pm 21.6$ & $81.0 \pm 17.6$ & $84.4 \pm 20.8$ & $84.1 \pm 15.8$ & 0.427 \\
\hline iPTH, pg/mL & $349.0 \pm 292.2$ & $307.2 \pm 281.3$ & $368.2 \pm 238.2$ & $382.9 \pm 368.8$ & $391.7 \pm 295.6$ & 0.587 \\
\hline TAST, \% & $0.3 \pm 0.2$ & $0.3 \pm 0.2$ & $0.4 \pm 0.2$ & $0.3 \pm 0.2$ & $0.4 \pm 0.2$ & 0.407 \\
\hline Fe (iron), $\mu \mathrm{mol} / \mathrm{L}$ & $48.1 \pm 44.1$ & $48.4 \pm 49.8$ & $50.7 \pm 42.0$ & $44.4 \pm 33.0$ & $42.5 \pm 40.4$ & 0.909 \\
\hline
\end{tabular}


statistical significance. All statistical analyses were performed using Statistical Package for the Social Sciences (SPSS) version 20.0 for Windows (SPSS Inc., Chicago, IL, USA).

\section{Results}

\section{Baseline characteristics of the study subjects}

A total of 221 PD patients were included, and the baseline demographic, clinical, and laboratory characteristics are shown in Table 1. The mean age was $53.0 \pm 14.1$ years, the female/male composition was122/99, and the median follow-up time was 35 (3 109) months. During the follow-up period, 50 (22.6\%) patients died. The underlying kidney diseases were chronic glomerulonephritis (42.1\%), diabetic nephropathy (23.1\%), hypertensive nephropathy (14.0\%), obstructive nephropathy (8.1\%), lupus nephritis $(7.7 \%)$ and others (5.0\%).

\section{Comparison of the low and high ferritin groups at baseline}

The cutoff value of $100 \mu \mathrm{g} / \mathrm{L}$ was determined based on clinical practice recommendations (Kidney Disease Outcomes Quality Initiative [KDOQI] 2006 [13], Kidney Disease: Improving Global Outcomes [KDIGO] 2012 [14], and The Japanese Society for Dialysis Therapy (JSDT) guidelines [15, 16] and previous research [17]. A standard hsCRP level of $3 \mathrm{mg} / \mathrm{L}$ was determined according to the recommendation of the American Heart Association [18]. The patients were divided into the following four groups on the basis of serum ferritin and hsCRP levels: ferritin $\geq 100 \mu \mathrm{g} / \mathrm{L}$ and hsCRP $>3 \mathrm{mg} / \mathrm{L}$, ferritin $\geq 100 \mu \mathrm{g} / \mathrm{L}$ and hsCRP $\leq 3 \mathrm{mg} / \mathrm{L}$, ferritin $<100 \mu \mathrm{g} / \mathrm{L}$ and hsCRP $>3 \mathrm{mg} / \mathrm{L}$, and ferritin $<100 \mu \mathrm{g} / \mathrm{L}$ and hsCRP $\leq 3$ $\mathrm{mg} / \mathrm{L}$. As shown in Table 1 , patients in the ferritin $\geq 100 \mu \mathrm{g} / \mathrm{L}$ and hsCRP $>3 \mathrm{mg} / \mathrm{L}$ group had a higher proportion of males and higher all-cause mortality (32.3\%) and cardiovascular mortality (15.6\%). These four groups showed no significant differences in age, BMI, 24-h urine amount, blood pressure, Kt/V, PET, BUN, serum creatinine, phosphorus, calcium, cholesterol, triglyceride, LDL-C, HDL-C, apolipoprotein A, uric acid, albumin, prealbumin, hemoglobin iron and TSAT.

\section{Correlation between serum ferritin and clinical variables at baseline}

The correlation between serum ferritin and clinical parameters was analyzed by Spearman's correlation method (Table 2). Serum ferritin was significantly correlated with male sex and positively related to BUN and uric acid. However, in the multiple linear regression analysis, including significant variables from the univariate analysis, no clinical parameters were notably correlated with ferritin levels including hsCRP $(P>0.05)$.
Table 2 Characteristics and correlation between serum ferritin levels and clinical variables at baseline

\begin{tabular}{|c|c|c|}
\hline & Spearman $r$ & $P$ value \\
\hline Age, years & 0.015 & 0.859 \\
\hline Male, $n(\%)$ & -0.282 & 0.000 \\
\hline Duration of $\mathrm{PD}$, months & -0.186 & 0.070 \\
\hline $24 \mathrm{~h}$ Urine Amount, $\mathrm{mL}$ & 0.027 & 0.760 \\
\hline $\mathrm{SBP}, \mathrm{mmHg}$ & 0.043 & 0.548 \\
\hline $\mathrm{DBP}, \mathrm{mmHg}$ & 0.022 & 0.762 \\
\hline $\mathrm{Kt} / \mathrm{N}$ & -0.053 & 0.819 \\
\hline $\mathrm{BUN}, \mathrm{mmol} / \mathrm{L}$ & 0.156 & 0.020 \\
\hline Creatinine, $\mu \mathrm{mol} / \mathrm{L}$ & 0.011 & 0.871 \\
\hline Phosphorus, mmol/L & 0.098 & 0.146 \\
\hline Calcium, mmol/L & 0.038 & 0.580 \\
\hline Cholesterol, mmol/L & -0.065 & 0.339 \\
\hline Triglyceride, mmol/L & -0.153 & 0.065 \\
\hline $\mathrm{LDL}-\mathrm{C}, \mathrm{mmol} / \mathrm{L}$ & -0.044 & 0.514 \\
\hline $\mathrm{HDL}-\mathrm{C}, \mathrm{mmol} / \mathrm{L}$ & -0.090 & 0.188 \\
\hline apolipoprotein A, g/L & -0.114 & 0.171 \\
\hline Uric acid, $\mu \mathrm{mol} / \mathrm{L}$ & 0.153 & 0.026 \\
\hline hsCRP, mg/L & 0.116 & 0.088 \\
\hline Albumin, g/L & 0.029 & 0.669 \\
\hline Prealbumin, $g / L$ & 0.063 & 0.388 \\
\hline Hemoglobin, g/L & -0.118 & 0.083 \\
\hline TAST, $\%$ & 0.086 & 0.223 \\
\hline $\mathrm{Fe}$ (iron), $\mu \mathrm{mol} / \mathrm{L}$ & 0.045 & 0.588 \\
\hline
\end{tabular}

Values expressed as Spearman's correlation coefficient $r$

\section{Survival analysis}

The ability of serum ferritin to predict mortality during a median follow-up of 35 month was examined. Of the 221 patients with PD, 50 died during follow-up, and the most common cause of death was cardiovascular disease (46.0\%), followed by infection (10.0\%). Kaplan-Meier curves showed higher mortality among PD patients in the high ferritin group with hsCRP above $3 \mathrm{mg} / \mathrm{L}$ (Logrank test, $P=0.022$ ) (Fig. 1 ). In contrast, no significant difference in mortality was observed among patients with hsCRP levels less than $3 \mathrm{mg} / \mathrm{L}$ (data not shown). A Cox proportional hazard model was further applied to assess the independent predictors of all-cause and cardiovascular mortality in PD patients. A multivariate analysis was performed after adjusting for age, gender and other confounding factors (factors with $P<0.10$ in the univariate analysis) under the condition of high hsCRP levels (> $3 \mathrm{mg} / \mathrm{L}$ ), and serum ferritin level was identified as an independent risk factor for all-cause and cardiovascular mortality (HR: 3.114, $P=0.021$; HR: 9.382, $P=$ 0.032) (Table 3, Fig. 2). The statistical power results were 0.9107 and 0.9958 for the multivariate Cox 


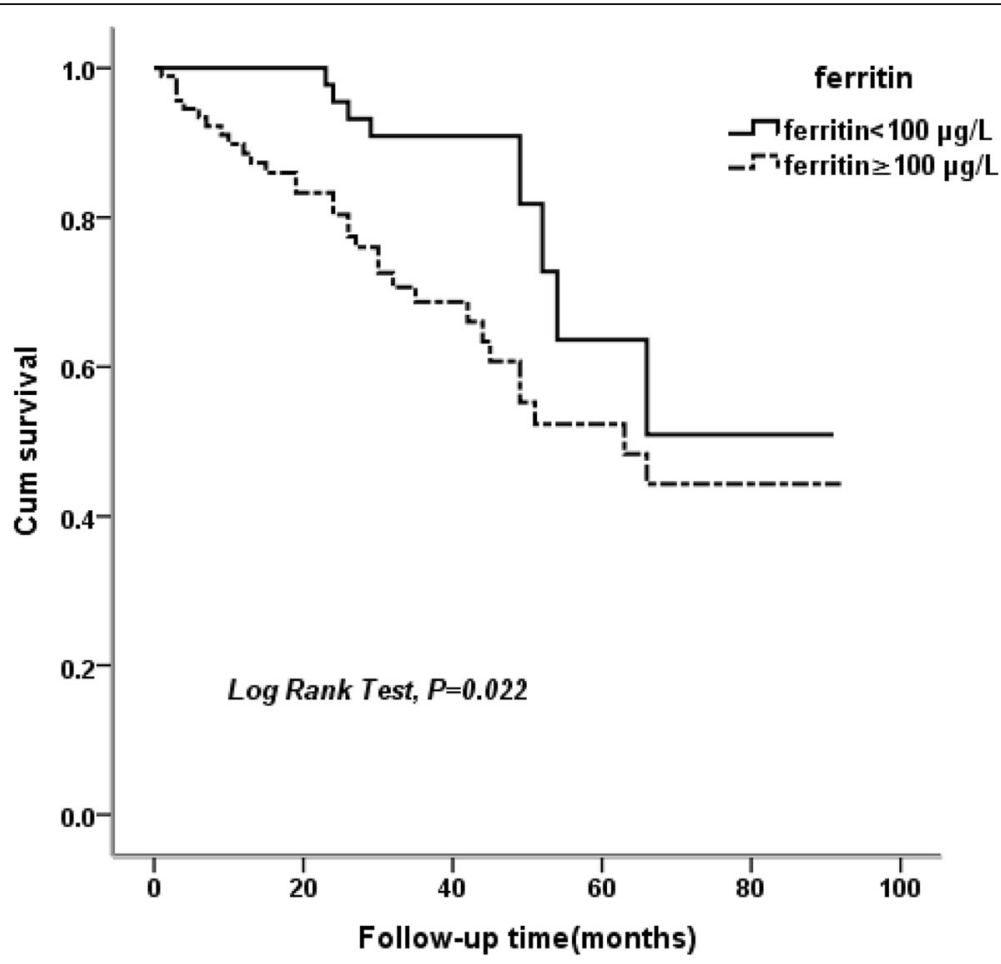

Fig. 1 Kaplan-Meier survival curves depicting the survival probability based on serum ferritin under elevated hsCRP levels (> $3 \mathrm{mg} / \mathrm{L})$ among PD patients during follow-up time

regression analyses of serum ferritin with all-cause and cardiovascular mortality, respectively. However, the correlations of serum ferritin with poor outcome were not statistically significant under the condition of low hsCRP levels (Supplementary Table 1). In addition, the multivariate analysis showed that uric acid was associated with all-cause mortality (HR: $1.003, P=0.040$ ), and age was associated with cardiovascular mortality (HR: 2.991, $P=0.042$ ) (Table 3).

\section{Discussion}

The present study demonstrates that systemic inflammation has an important effect on the relationship between serum ferritin and the survival of patients undergoing PD. Our results show that a relatively high ferritin level is an independent risk factor for all-cause and cardiovascular mortality among PD patients only in the presence of elevated hsCRP levels.

Serum ferritin has been widely recognized as an acute phase reactant and marker of acute and chronic inflammation independent of its classic role as an iron delivery protein $[3,19]$. It is nonspecifically enhanced in several disorders, including liver disease, coronary artery disease, rheumatoid arthritis, and cancer [1, 4, 20, 21]. Additionally, elevated serum ferritin levels have been observed in patients with renal impairment, and these elevated levels are closely related to a higher risk of CKD, a rapid decline in renal function and progression to renal replacement therapy (RRT) [22-24]. Accumulating evidence has demonstrated that hyperferritinemia is significantly associated with poor prognosis, including higher mortality in MHD and PD patients [6, 25-27], although the threshold values at which serum ferritin contributes to negative outcomes differ between MHD and PD patients; these ferritin levels are higher than the demand for erythropoiesis.

Although the mechanisms underlying the association of higher ferritin levels with mortality are incompletely understood, some explanations have been proposed. Serum ferritin leaks from damaged cells, losing most of its iron on the way, and this released iron is in an unliganded form that can negatively impact health and stimulate further cell damage [28]. Moreover, human circulating ferritin can induce oxidative stress by releasing iron with aminolevulinate, a uremic toxin [29]. These results are in accord with our observation that increased ferritin levels are associated with higher mortality in PD patients.

Inflammation plays a pivotal pathogenic role in ESKD, which is caused by multiple factors, including uremic toxins, dialysis, and comorbidities [30, 31]. Researchers recently proposed that inflammation may modify the association between some clinical indicators and the longterm prognosis of ESKD patients [11, 12, 32]. Thus, in 
Table 3 Cox proportional hazard analyses of all-cause and cardiovascular mortality under high hsCRP level $>3$ mg/L

\begin{tabular}{|c|c|c|c|c|}
\hline \multicolumn{5}{|c|}{ Univariate analysis of mortality } \\
\hline & \multicolumn{2}{|l|}{ All-cause mortality } & \multicolumn{2}{|l|}{ Cardiovascular mortality } \\
\hline & $\mathrm{HR}(95 \% \mathrm{Cl})$ & $P$ value & HR $(95 \% \mathrm{Cl})$ & $P$ value \\
\hline Age, years & $1.281(0.651-2.522)$ & 0.474 & $1.785(0.614-5.192)$ & 0.287 \\
\hline Male, n (\%) & $0.821(0.431-1.566)$ & 0.550 & $1.055(0.416-2.675)$ & 0.910 \\
\hline $24 \mathrm{~h}$ Urine Amount, mL & $1.000(0.999-1.001)$ & 0.998 & $1.002(0.999-1.004)$ & 0.131 \\
\hline $\mathrm{SBP}, \mathrm{mmHg}$ & $1.006(0.990-1.002)$ & 0.471 & $1.000(0.975-1.026)$ & 0.993 \\
\hline $\mathrm{DBP}, \mathrm{mmHg}$ & $0.990(0.964-1.017)$ & 0.481 & $0.980(0.941-1.021)$ & 0.329 \\
\hline $\mathrm{Kt} / \mathrm{N}$ & $1.604(0.373-2.903)$ & 0.526 & $0.841(0.131-5.393)$ & 0.855 \\
\hline PET D/Pcr & $0.908(0.782-63.3)$ & 0.482 & $0.965(0.689-1.688)$ & 0.848 \\
\hline BUN, mmol/L & $1.006(0.999-1.012)$ & 0.101 & $1.009(1.002-1.015)$ & 0.008 \\
\hline Creatinine, $\mu \mathrm{mol} / \mathrm{L}$ & $1.000(0.998-1.001)$ & 0.559 & $1.000(0.998-1.001)$ & 0.780 \\
\hline Phosphorus, mmol/L & $0.896(0.558-1.437)$ & 0.648 & $1.076(0.582-1.989)$ & 0.815 \\
\hline Calcium, mmol/L & $1.170(0.469-2.917)$ & 0.736 & $1.015(0.306-3.985)$ & 0.879 \\
\hline Cholesterol, mmol/L & $0.909(0.743-1.112)$ & 0.353 & $1.042(0.805-1.348)$ & 0.757 \\
\hline Triglyceride, mmol/L & $1.009(0.706-1.440)$ & 0.963 & $1.290(0.772-2.157)$ & 0.332 \\
\hline $\mathrm{LDL}-\mathrm{C}, \mathrm{mmol} / \mathrm{L}$ & $0.709(0.248-2.028)$ & 0.521 & $0.510(0.099-2.631)$ & 0.421 \\
\hline $\mathrm{HDL}-\mathrm{C}, \mathrm{mmol} / \mathrm{L}$ & $0.879(0.666-1.161)$ & 0.363 & $0.975(0.672-1.414)$ & 0.894 \\
\hline apolipoproteinA, g/L & $1.095(0.165-7.246)$ & 0.925 & $5.919(0.265-132.113)$ & 0.262 \\
\hline Ferritin, $\mu \mathrm{g} / \mathrm{L}$ & $2.412(1.104-5.271)$ & 0.027 & $2.920(0.839-10.162)$ & 0.092 \\
\hline Uric acid, $\mu \mathrm{mol} / \mathrm{L}$ & $1.003(1.000-1.006)$ & 0.021 & $1.004(1.000-1.007)$ & 0.062 \\
\hline hs-CRP, mg/L & $1.002(0.995-1.009)$ & 0.558 & $1.002(0.991-1.021)$ & 0.749 \\
\hline Albumin, $g / L$ & $0.991(0.942-1.042)$ & 0.719 & $1.026(0.934-1.128)$ & 0.592 \\
\hline Prealbumin, g/L & $0.884(0.583-1.339)$ & 0.560 & $0.919(0.609-1.387)$ & 0.686 \\
\hline Hemoglobin, g/L & $0.995(0.982-1.009)$ & 0.515 & $0.902(0.982-1.020)$ & 0.902 \\
\hline TAST, \% & $1.001(0.986-1.017)$ & 0.849 & $0.998(0.974-1.021)$ & 0.846 \\
\hline $\mathrm{Fe}$ (iron), $\mu \mathrm{mol} / \mathrm{L}$ & $0.997(0.990-1.004)$ & 0.428 & $1.001(0.993-1.009)$ & 0.748 \\
\hline \multicolumn{5}{|c|}{ Multivariate analysis of mortality } \\
\hline Ferritin, $\mu \mathrm{g} / \mathrm{L}$ & $3.114(1.118-8.162)$ & 0.021 & $9.382(1.123-72.581)$ & 0.032 \\
\hline Age, years & - & - & $2.991(1.040-8.598)$ & 0.042 \\
\hline Uric acid, $\mu \mathrm{mol} / \mathrm{L}$ & $1.003(1.000-1.006)$ & 0.040 & - & - \\
\hline
\end{tabular}

Values express as hazard ratio (HR) and $95 \%$ confidence interval( $95 \% \mathrm{Cl})$

this study, we questioned whether the correlation of higher serum ferritin with mortality is linked to systemic inflammation and investigated the optimal serum ferritin level for predicting death when considering inflammation in PD patients.

Currently, there are limited data from which to determine the safe cutoff values for serum ferritin levels to appropriately treat anemia in PD patients without evoking obvious negative. Hur S M et al. showed that elevated serum ferritin levels $(>250 \mu \mathrm{g} / \mathrm{L}$ ) was significantly associated with a more rapid RRF decline in patients undergoing PD [27]. CKD patients with ferritin levels above $288 \mu \mathrm{g} / \mathrm{L}$ were more likely to have adverse renal outcomes [24]. In our cohort, a cutoff value for ferritin of $100 \mu \mathrm{g} / \mathrm{L}$ was selected based on the largely opinion- based clinical practice recommendations KDOQI 2006 [13] and KDIGO 2012 [14], which state that supplemental iron should be administered to maintain ferritin levels $>100 \mu \mathrm{g} / \mathrm{L}$ in CKD5 PD patients. Moreover, Kuragano et al. performed a prospective, observational, multicenter study of 1086 Japanese HD patients and found that hyperferritinemia, defined as serum ferritin > $100 \mu \mathrm{g} / \mathrm{L}$, is a risk factor for cardiovascular disease, infection, hospitalization and death [17].

In this study, mortality was higher among PD patients with serum ferritin values $\geq 100 \mu \mathrm{g} / \mathrm{L}$ than among those with ferritin levels $<100 \mu \mathrm{g} / \mathrm{L}$ (Table 1). To ascertain whether systemic inflammation affects the association between serum ferritin and mortality risk, we used Kaplan-Meier survival analyses and Cox survival models 


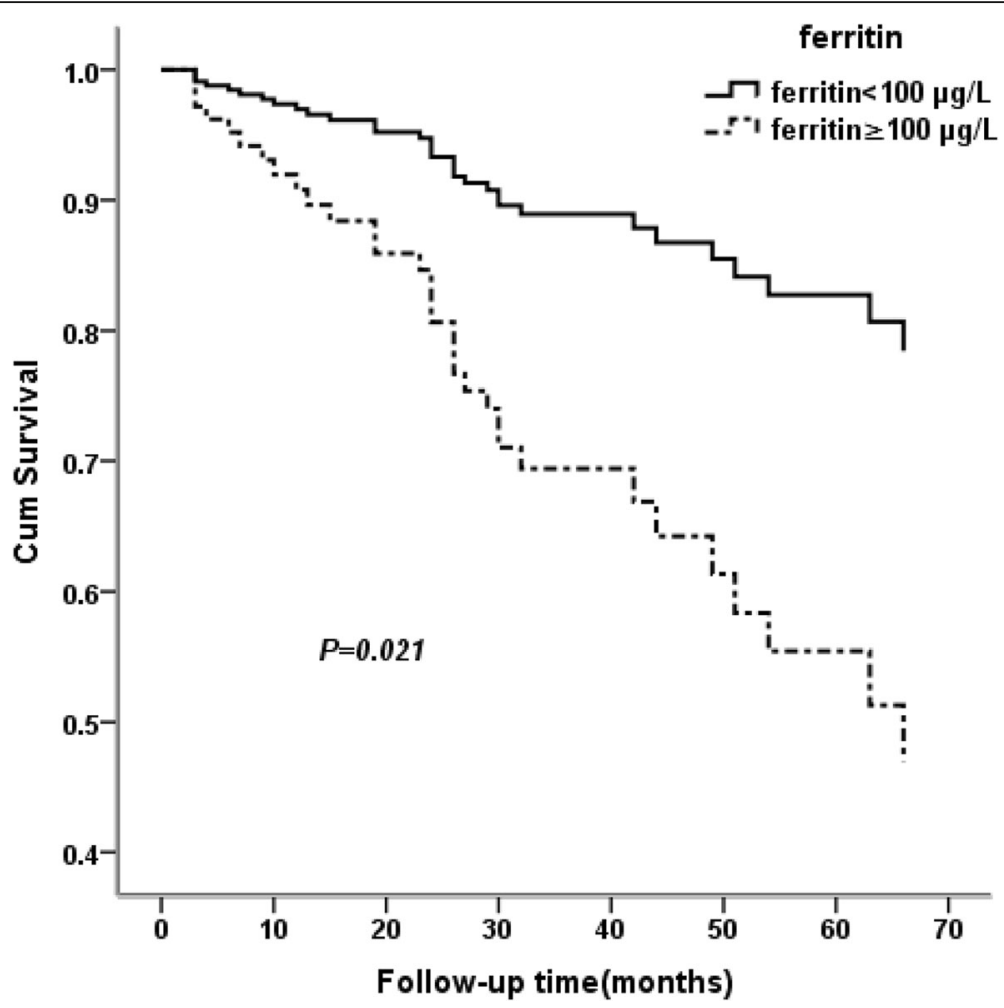

Fig. 2 Survival probability with respect to serum ferritin under elevated hsCRP levels ( $>3 \mathrm{mg} / \mathrm{L}$ ) by multivariate cox proportional hazards regression analysis with age, gender and other confounding risk factors adjusted

to confirm that hyperferritinemia is an independent predictor of all-cause and cardiovascular mortality after adjusting for age, gender and other relevant confounding factors in the hsCRP $>3 \mathrm{mg} / \mathrm{L}$ group, but not in the hsCRP $<3 \mathrm{mg} / \mathrm{L}$ group. Our study demonstrated a dramatic catalytic effect of inflammation on the association between serum ferritin and unfavorable prognosis in PD patients.

A Ferritin-mediated feed-forward inflammatory loop might explain why serum ferritin has predictive power in PD patients with inflammation. Ferritin molecules are composed of heavy $(\mathrm{H})$ and light $(\mathrm{L})$ chain subunits. Inflammatory cytokines upregulate ferritin synthesis by increasing both the $\mathrm{H}$ and $\mathrm{L}$ subunits [33], especially the translation of $\mathrm{H}$ chain mRNA through direct interactions with the $5^{\prime}$ UTR $[34,35]$. A positive feedback loop ensues in which ferritin production downstream of TLR9 activation leads to increased amplification of inflammatory signals [36]. In addition, published data have indicated that persistent inflammation in the uremic milieu might exacerbate the effect of other concurrent risk factors by increasing signaling through the inflammatory cascade and exacerbating both the wasting and vascular calcification processes [12].

Although higher serum ferritin is always related to inflammation under various inflammatory conditions, we did not find a positive correlation between serum ferritin and hsCRP in this study. Some factors may be responsible for this inconsistency. Serum ferritin levels are influenced by multiple factors, especially in ESKD patients, who are always treated with iron supplementation, which significantly increases serum ferritin levels without apparent inflammation. Additionally, in this study, most PD patients were not complicated by acute infection and were sufficiently healthy to undergo percutaneous PD catheter insertion. These abovementioned reasons may explain the lack of a correlation between serum ferritin and hsCRP in this study.

Some limitations need to be considered. First, this was a retrospective, observational study conducted at a single center with a relatively small sample size. Second, we used a single serum ferritin concentration determined at baseline in accordance with similar published studies about the effect of serum ferritin in dialysis patients [27, 37]. However, the mean serum ferritin level has been reported to not change over a 1 -year period, indicating consistent levels after the start of PD [27]. Finally, biomarkers of inflammation other than hsCRP, including IL- 1 , TNF- $\alpha$ and IFN- $\gamma$, were not analyzed due to incomplete clinical records; nonetheless, hsCRP is a more sensitive inflammatory biomarker than the others [10]. 


\section{Conclusion}

In conclusion, a high serum ferritin level $(\geq 100 \mu \mathrm{g} / \mathrm{L})$ was positively associated with a higher risk of all-cause and cardiovascular mortality in patients undergoing PD only in the presence of an elevated hsCRP level ( $>3 \mathrm{mg}$ / L). The correlation of serum ferritin with the reduced long-term survival of PD patients should take into consideration systemic inflammation.

\section{Supplementary information}

Supplementary information accompanies this paper at https://doi.org/10. 1186/s12882-020-01892-9.

Additional file 1: Supplementary Table 1. Cox proportional hazard analyses of all-cause and cardiovascular mortality with low hsCRP levels $(\leq 3 \mathrm{mg} / \mathrm{L})$

\section{Abbreviations}

PD: Peritoneal dialysis; hsCRP: High-sensitivity C-reactive protein; CKD: Chronic kidney disease; ROS: Reactive oxygen species; CRP: C-reactive protein; ESKD: End stage kidney disease; CAPD: Continuous ambulatory peritoneal dialysis; ESA: Erythropoiesis-stimulating agent; BMI: Body mass index; SBP: Systolic blood pressure; DBP: Diastolic blood pressure; PET: Peritoneal membrane transport; BUN: Blood urea nitrogen; TSAT: Transferrin saturation; SD: Standard deviation; KDOQI: Kidney Disease Outcomes Quality Initiative; KDIGO: Kidney Disease: Improving Global Outcomes; HR: Hazard ratio; RRT: Renal replacement therapy; MHD: Maintenance hemodialysis

\section{Acknowledgments}

The authors appreciate the assistance of all participants.

\section{Authors' contributions}

Conceived and designed the study: YT, AX. Collected Data: SF, JC, BL, PL, YZ. Analyzed and interpreted the data: SF, YT, MF, ZX. Performed statistical analysis: SF, JC, GZ, SY. Contributed to the writing of the manuscript: YT, SF, $J C, B L, P L, Y Z$. Revised the manuscript: YT, AX, SF, JC, BL. All authors have read and approved the manuscript.

\section{Funding}

This work was supported by a grant from the National Natural Science Foundation of China (Grant No.81800595) which paid for the statistical consulting and language polishing service. The funding source had no role in the design of the study, collection, analysis and interpretation of data, and in writing and submitting the manuscript.

\section{Availability of data and materials}

The datasets used and/or analyzed during the current study are available from the corresponding author on reasonable request.

\section{Ethics approval and consent to participate}

The study was conducted in accordance with the Declaration of Helsinki (2013). Patient data analyses were conducted retrospectively using identified patient data and the manuscript contains no individual data in any form. The study and protocol were reviewed and approved by the Medical Ethics Committee of SunYat-Sen Memorial Hospital, Sun Yat-Sen University. We reviewed and followed up the medical data according to the guidelines of our ethics committee. Oral informed consent from PD patients were obtained if we followed up by telephone

\section{Consent for publication}

Not applicable.

\section{Competing interests}

The authors declare that they have no competing interests.
Received: 28 August 2019 Accepted: 11 June 2020

Published online: 23 June 2020

\section{References}

1. Khanna V, Karjodkar F, Robbins S, Behl M, Arya S, Tripathi A. Estimation of serum ferritin level in potentially malignant disorders, oral squamous cell carcinoma, and treated cases of oral squamous cell carcinoma. J Cancer Res Ther. 2017;13(3):550-5.

2. Tappin JA, George WD, Bellingham AJ. Effect of surgery on serum ferritin concentration in patients with breast cancer. Br J Cancer. 1979;40(4):658-60.

3. Kalantar-Zadeh K, Kalantar-Zadeh K, Lee GH. The fascinating but deceptive ferritin: to measure it or not to measure it in chronic kidney disease? Clin J Am Soc Nephrol. 2006:1(Suppl 1):S9-18.

4. Maiwall R, Kumar S, Chaudhary AK, Maras J, Wani Z, Kumar C, et al. Serum ferritin predicts early mortality in patients with decompensated cirrhosis. J Hepatol. 2014;61(1):43-50.

5. Elia G, Polla B, Rossi A, Santoro MG. Induction of ferritin and heat shock proteins by prostaglandin A1 in human monocytes. Evidence for transcriptional and post-transcriptional regulation. Eur J Biochem. 1999; 264(3):736-45.

6. Ogawa C, Tsuchiya K, Kanda F, Maeda T. Low levels of serum ferritin lead to adequate hemoglobin levels and good survival in hemodialysis patients. Am J Nephrol. 2014;40(6):561-70

7. Lien CT, Lin KC, Tsai YF, Yu LK, Huang LH, Chen CA. Serum ferritin is associated with progression of peripheral arterial disease in hemodialysis patients. Clin Exp Nephrol. 2015;19(5):947-52.

8. Yeun JY, Levine RA, Mantadilok V, Kaysen GA. C-reactive protein predicts allcause and cardiovascular mortality in hemodialysis patients. Am J Kidney Dis. 2000;35(3):469-76.

9. Liu SH, Chen CY, Li YJ, Wu HH, Lin CY, Chen YC, et al. The value of timeaveraged serum high-sensitivity C-reactive protein in prediction of mortality and dropout in peritoneal dialysis patients. Ther Clin Risk Manag. 2017;13: 1009-21.

10. Corrado $E$, Novo $S$. High sensitivity of C-reactive protein in primary prevention. G Ital Cardiol (Rome). 2007:8(6):327-34.

11. Alves FC, Sun J, Qureshi AR, Dai L, Snaedal S, Barany P, et al. The higher mortality associated with low serum albumin is dependent on systemic inflammation in end-stage kidney disease. PLoS One. 2018;13(1):e0190410.

12. Carrero JJ, Stenvinkel P. Persistent inflammation as a catalyst for other risk factors in chronic kidney disease: a hypothesis proposal. Clin J Am Soc Nephrol. 2009;4(Suppl 1):S49-55.

13. KDOQI. Clinical practice guidelines and clinical practice recommendations for anemia in chronic kidney disease. Am J Kidney Dis. 2006;47(suppl 3):S58-70.

14. KDIGO. Clinical Practice Guideline for Anemia in Chronic Kidney Disease. Kidney Int Suppl (2011). 2012; 2:279-335.

15. Gejyo F, Saito A, Akizawa T, Akiba T, Sakai T, Suzuki M, et al. 2004 Japanese Society for Dialysis Therapy guidelines for renal anemia in chronic hemodialysis patients. Ther Apher Dial. 2004:8(6):443-59.

16. Tsubakihara Y, Nishi S, Akiba T, Hirakata H, Iseki K, Kubota M, et al. 2008 Japanese Society for Dialysis Therapy: guidelines for renal anemia in chronic kidney disease. Ther Apher Dial. 2010;14(3):240-75.

17. Kuragano T, Matsumura O, Matsuda A, Hara T, Kiyomoto H, Murata T, et al. Association between hemoglobin variability, serum ferritin levels, and adverse events/mortality in maintenance hemodialysis patients. Kidney Int. 2014:86(4):845-54

18. Ridker PM. Cardiology patient page. C-reactive protein: a simple test to help predict risk of heart attack and stroke. Circulation. 2003;108(12):e81-5.

19. Ganz T, Nemeth E. Iron sequestration and anemia of inflammation. Semin Hematol. 2009:46(4):387-93.

20. Zhou Y, Liu T, Tian C, Kang P, Jia C. Association of serum ferritin with coronary artery disease. Clin Biochem. 2012:45(16-17):1336-41.

21. LV F, Song $L$, Li XF. Combined measurement of multiple acute phase reactants to predict relapse of rheumatoid arthritis. Int J Rheum Dis. 2015; 18(7):725-30.

22. Kang HT, Linton JA, Kwon SK, Park BJ, Lee JH. Ferritin level is positively associated with chronic kidney disease in Korean men, based on the 20102012 Korean National Health and nutrition examination survey. Int J Environ Res Public Health. 2016:13(11):1058.

23. Kovesdy CP, Estrada W, Ahmadzadeh S, Kalantar-Zadeh K. Association of markers of iron stores with outcomes in patients with nondialysisdependent chronic kidney disease. Clin J Am Soc Nephrol. 2009;4(2):435-41. 
24. Tsai YC, Hung CC, Kuo MC, Tsai JC, Yeh SM, Hwang SJ, et al. Association of hsCRP, white blood cell count and ferritin with renal outcome in chronic kidney disease patients. PLoS One. 2012;7(12):e52775.

25. Kalantar-Zadeh K, Don BR, Rodriguez RA, Humphreys MH. Serum ferritin is a marker of morbidity and mortality in hemodialysis patients. Am J Kidney Dis. 2001;37(3):564-72.

26. Bavbek N, Yilmaz H, Erdemli HK, Selcuki Y, Duranay M, Akcay A. Correlation between iron stores and QTC dispersion in chronic ambulatory peritoneal dialysis patients. Ren Fail. 2014;36(2):187-90

27. Hur SM, Ju HY, Park MY, Choi SJ, Kim JK, Hwang SD. Ferritin as a predictor of decline in residual renal function in peritoneal dialysis patients. Korean Intern Med. 2014;29(4):489-97.

28. Kell DB, Pretorius E. Serum ferritin is an important inflammatory disease marker, as it is mainly a leakage product from damaged cells. Metallomics. 2014:6:748-73.

29. Hasuike $\mathrm{Y}$, Nonoguchi H, Tokuyama M, Hata R, Kitamura R, Hori K, et al. Pathological role of aminolevulinate in uremic patients. Ther Apher Dial. 2011;15(1):28-33.

30. Carrero JJ, Stenvinkel P. Inflammation in end-stage renal disease--what have we learned in 10 years? Semin Dial. 2010;23(5):498-509.

31. Shankar A, Sun L, Klein BE, Lee KE, Muntner P, Nieto FJ, et al. Markers of inflammation predict the long-term risk of developing chronic kidney disease: a population-based cohort study. Kidney Int. 2011;80(11):1231-8.

32. Stenvinkel P, Gillespie IA, Tunks J, Addison J, Kronenberg F, Drueke TB, et al. Inflammation modifies the paradoxical association between body mass index and mortality in hemodialysis patients. J Am Soc Nephrol. 2016;27(5): 1479-86.

33. Rogers JT, Bridges KR, Durmowicz GP, Glass J, Auron PE, Munro HN Translational control during the acute phase response. Ferritin synthesis in response to interleukin-1. J Biol Chem. 1990;265(24):14572-8.

34. Recalcati S, Invernizzi P, Arosio P, Cairo G. New functions for an iron storage protein: the role of ferritin in immunity and autoimmunity. J Autoimmun. 2008:30(1-2):84-9.

35. Torti FM, Torti SV. Regulation of ferritin genes and protein. Blood. 2002; 99(10):3505-16.

36. Kernan KF, Carcillo JA. Hyperferritinemia and inflammation. Int Immunol. 2017;29(9):401-9.

37. Hasuike $\mathrm{Y}$, Nonoguchi H, Tokuyama M, Ohue M, Nagai T, Yahiro M, et al. Serum ferritin predicts prognosis in hemodialysis patients: the Nishinomiya study. Clin Exp Nephrol. 2010;14(4):349-55.

\section{Publisher's Note}

Springer Nature remains neutral with regard to jurisdictional claims in published maps and institutional affiliations.

Ready to submit your research? Choose BMC and benefit from:

- fast, convenient online submission

- thorough peer review by experienced researchers in your field

- rapid publication on acceptance

- support for research data, including large and complex data types

- gold Open Access which fosters wider collaboration and increased citations

- maximum visibility for your research: over $100 \mathrm{M}$ website views per year

At $\mathrm{BMC}$, research is always in progress.

Learn more biomedcentral.com/submissions 